\title{
Case Report \\ Tuberculous Pericarditis Causing Severe Pericardial Effusion: A Case Study
}

\author{
Ahmad Amouzeshi ${ }^{1} \oplus$, Mahmoud Ganji Fard ${ }^{2}$, Nahid Azdaki ${ }^{3 *}$ (당
}

1. Cardiovascular Disease Research Center, Birjand University of Medical Sciences, Birjand, Iran.

2. Department of Anesthesiology, Birjand University of Medical Sciences, Birjand, Iran.

3. Department of Heart, Cardiovascular Disease Research Center, School of Medicine, Birjand University of Medical Sciences, Birjand, Iran.

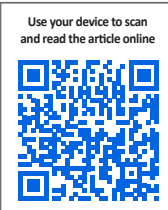

Citation Amouzeshi A, Ganji Fard M, Azdaki N. [Tuberculous Pericarditis Causing Severe Pericardial Effusion: A Case Study (Persian)]. Quarterly of "The Horizon of Medical Sciences". 2020; 26(2):192-199. https://doi.org/10.32598/hms.26.2.3169.1

doi https://doi.org/10.32598/hms.26.2.3169.1

\section{(i) (3)}

Received: 16 Jun 2019 Accepted: 25 Nov 2019 Available Online: 01 Apr 2020

Key words: Pericarditis, Tuberculous, Cardiac tamponade

\section{A B S T RACT}

Aims Tuberculous pericarditis is present in only one to two percent of the tuberculosis cases, i.e. considered rare. The disease is responsible for $4 \%$ and $7 \%$ of acute pericarditis and cardiac tamponade cases, respectively. Moreover, these conditions are associated with hazardous side effects. Thus, timely and precise diagnosis of the disease could prevent such complications.

Case report We reported an 85-year-old male case who was referred with clinical signs of breath shortness, cardiac murmur, and swollen jugular veins. Besides, the relevant laboratory findings indicated elevated white blood cell counts (11.6). In addition, other diagnostic measures, such as thoracic radiography and echocardiography were performed on the patient. Then, the diagnosis indicated a $28 \mathrm{~mm}$ diameter of pericardial fluid; accordingly, the patient was selected as a candidate for emergency pericardiotomy. The fluid was drained, and therapeutic medication, as well as antibiotics were administered for the patient. Finally, the patient was discharged with an appropriate general condition.

Conclusion A sample of pericardial fluid was tested using polymerase chain reaction)method for the diagnosis of tuberculosis, which provided a positive result. Considering the dangerous complications of this disease, it is recommended for all patients who could suction severe pericardial effusion to be tested for this disease.

\section{Extended Abstract}

\section{Introduction}

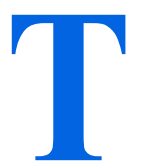

uberculosis (TB) cases has considerably declined in industrialized countries in recent years; however, Asia, Africa, and Latin America, with $86 \%$ of the world's population, account for $95 \%$ of active TB cases.

TB pericarditis, caused by mycobacterium TB, has been detected in almost $1 \%$ of all dissected TB cases [1]. Pericardial effusion is a fluid in the space between the heart and the pericardial membrane that fills the pericardial sac. It could be generated by issues, such as heart attack, heart failure, kidney failure, infection and malignancy, and myocardial infarction. The thickness of $>4 \mathrm{~mm}$ of pericardial fluid should be considered abnormal. This is because due to the limited space of pericardium, if not managed promptly and timely, it could impose pressure on the heart and cause tamponade [3]. The prompt treatment of TB pericarditis could be life-saving. Therefore, effective treatment requires a quick and accurate diagnosis for the disease, i.e. often difficult. The presented case was a patient with TB pericarditis whose condition had led to severe pericardial effusion.

\section{* Corresponding Author:}

Nahid Azdaki, PhD.

Address: Department of Heart, Cardiovascular Disease Research Center, School of Medicine, Birjand University of Medical Sciences, Birjand, Iran.

Tel: +98 (56) 31626000

E-mail: nahidazdaki@yahoo.com 


\section{Case Report}

The patient was an 85-year-old man who complained of weakness, lethargy, dizziness, and shortness of breath for $>5$ days. He reported no vomiting, sweating, or nausea; however, in the last few days, he experienced fever and shortness of breath. No specific case was reported in his family history, and there was no history of TB. Clinical findings were as follows: Pulses were full and symmetrical, organs lacked edema and cyanosis, vague heart was sound, there was a swelling of the jugular vein, as well as a wheezing sound in the right lung. Vital signs of the patient at the time of referral included blood pressure: $11.8 \mathrm{mmHg}$, pulse: $78 \mathrm{bpm}$, and body temperature: $38^{\circ} \mathrm{C}$. Test results were as follows: Hemoglobin $12.5 \mathrm{gr} / \mathrm{dL}, \mathrm{RBC}: 4.91 \mathrm{M} /$ uL, WBC: 11.6 thousand per mL, platelet: 328 thousand, and ESR: $50 \mathrm{~mm} / \mathrm{h}$. A sinus tachycardia was observed on the patient's ECG and a cardiomegaly was detected on his chest (Figure 1). Initially, we performed an echocardiogram and received a report of severe pericardial effusion of $28 \mathrm{~mm}$. Then, the patient was nominated for emergency pericardiotomy and the evacuation of pericardial effusion. Surgical incisions were conducted in the subxiphoid region and pericardial fluid was drained at $500 \mathrm{CC}$. The patient was implanted with a drain and transferred to the Cardiac Intensive Care Unit (CICU). The patient was prescribed cefazolin $1 \mathrm{~g}$ every 6 hours and clindamycin $600 \mathrm{~g}$ every 8 hours. Then, he was discharged after his symptoms of shortness of breath, fever, and white blood cell decreased and his general condition improved. The pericardial fluid and tissue sample was provided for pathology; accordingly, the response to the pericardial fluid sample was transferred for TB diagnosis and a Polymerase Chain Reaction (PCR) test was performed.

\section{Discussion}

Tuberculous pericarditis is the most frequent cause of pericarditis in Africa and other countries where TB remains a major problem. According to reports, TB accounts for 4\% of acute pericarditis and 7\% of cardiac tamponades. Moreover, the rate of TB mortality ranges between $14 \%$ and $40 \%$ [4]. Chest radiography suggested heart enlargement in $90 \%$ of cases, and the ECG is abnormal in tuberculous pericarditis. Heart enlargement was detected in the patients' chest CT scan; however, no sinus tachycardia was observed in the patient's ECG [1]. The pericardial effusion of $>2 \mathrm{~cm}$ could lead to fatal cardiac tamponade; therefore, it is necessary to take emergency action in a timely manner in this regard. According to the echocardiography report which mentioned $28 \mathrm{~mm}$ thickness of the pericardial effusion, as well as the clinical history, the presented patient had severe tamponade; however, his life was saved by a quick and effective operation.

Pericarditis usually presents with the symptoms of shortness of breath and sharp chest pain, and decreases with leaning forward while sitting. Pericardial abrasion may also be heard; however, this condition becomes non-obvious when fluid accumulates. The clinical manifestations of TB peri-

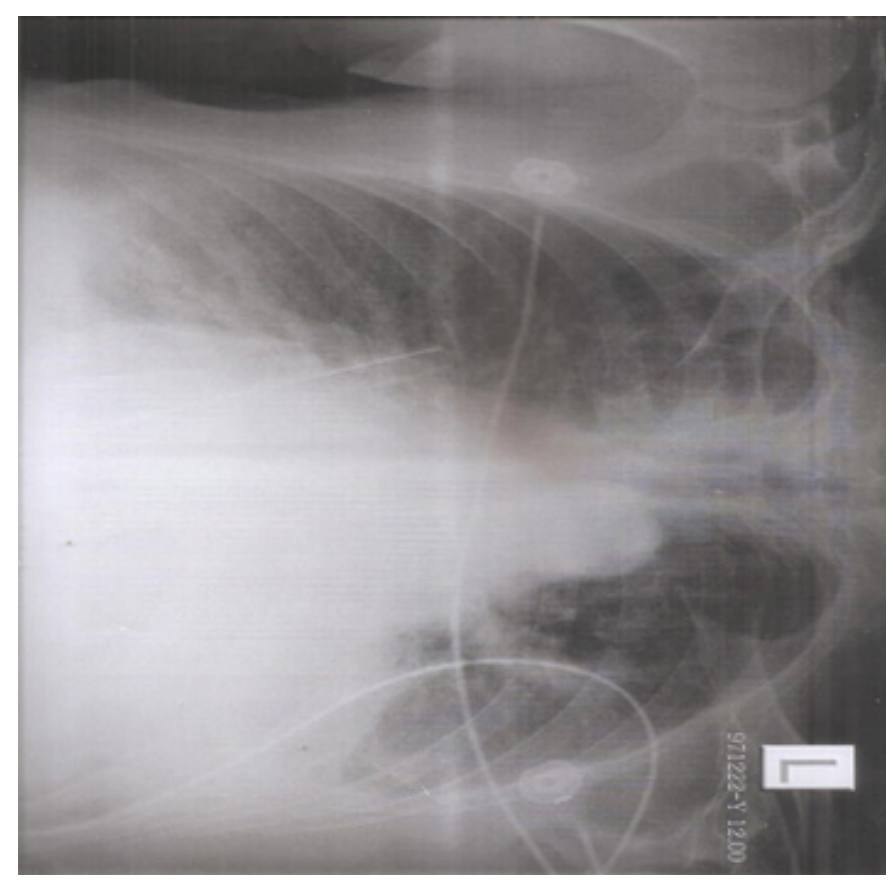

Figure 1. The cardiomegaly of the presented patient 
carditis are varied and unexplained. Besides, fever, fatigue, and weight loss are among the disease symptoms; however, the most common symptoms include cough, chest pain, and dyspnea [1].

Cardiac tamponade occurs when fluid accumulates in the pericardial space faster than its absorption rate in the pericardial sac. Subsequently, it could dilate and put a lot of pressure on the heart. This condition could be caused by a heart attack, heart failure, kidney failure, infection and malignancy, and myocardial infarction. The symptoms of tamponade include hypotension, swelling of the jugular vein, and a vague and complicated heart sound; the last two of which were present in our case [3].

In addition to the patient's clinical symptoms, echocardiography, and chest X-ray, PCR is applied to diagnose pericardial effusion. The rates of $>40 \mathrm{U} / \mathrm{L}$ is considered active [4], i.e. positive in our case due to this level (ADA: $58.4 \mathrm{IU} / \mathrm{L}$ ). However, an early and accurate diagnosis of this disease reduced the patient's symptoms and improved his condition. Medications used for TB pericarditis include 4 standard antituberculous drugs for a period of 6 months. Furthermore, daily prednisolone for at least two to three weeks is suggested, which was also prescribed for our patient.

\section{Conclusion}

Tuberculous pericarditis is a rare manifestation of TB. Given that it remains a deadly disease with high morbidity, early diagnosis and immediate action could prevent its symptoms and complications. Thus, PCR testing may be necessary for patients with pericardial effusion. Furthermore, some TB medications, like isoniazid, alone could cause pericarditis without fever.

\section{Ethical Considerations}

Compliance with ethical guidelines

All ethical principles were considered in this article.

\section{Funding}

This research did not receive any specific grant from funding agencies in the public, commercial, or non-profit sectors.

\section{Authors' contributions}

All authors contributed in designing, running, and writing all parts of the research.

\section{Conflicts of interest}

The authors declared no conflict of interest 


\title{
تَزارش يك مورد يريكارديت سلى منجر به يريكارديال افيورن شديد
}

\author{
احمد آموزشى' ف، محمود كنجىفرد'، "ناهيد ازدكى'ه \\ ا. مركز تحقيقات بيمارى هاى قلب و عروق، دانشكاه علوميزشكى بيرجئد، بيرجند، ايران.

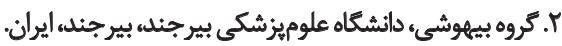

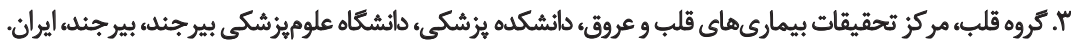

\begin{abstract}
حكبن

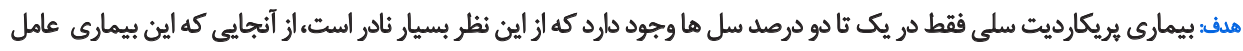

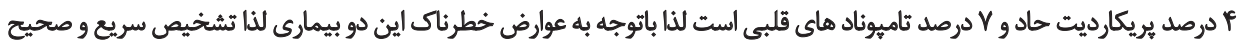

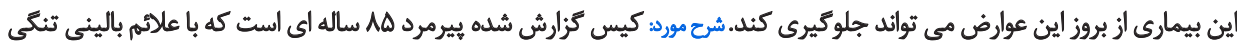

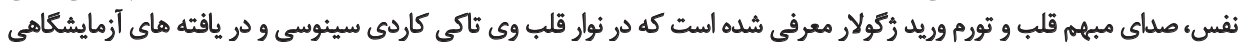

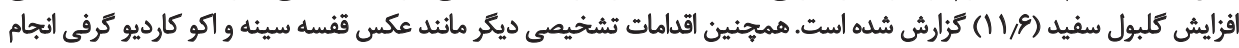

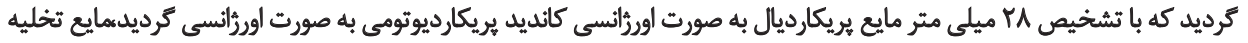

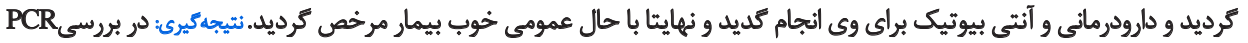

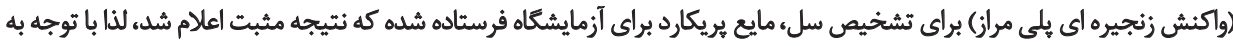

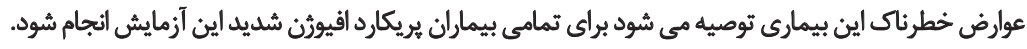

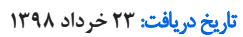

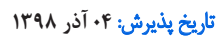

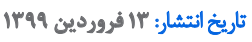

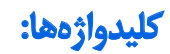

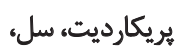

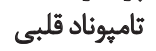

به آن يرداختهايم يك بيمار با تشخيص يريكارديت سلى است كه

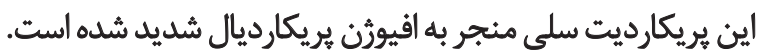

doles

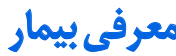

بيمار يك مرد هAرساله است كه با شكايت ضعف، بى حالى،

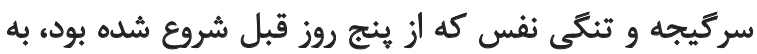

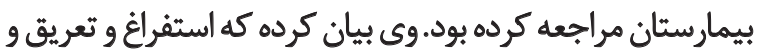

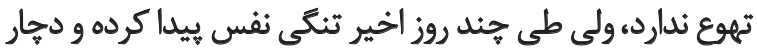

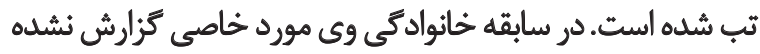

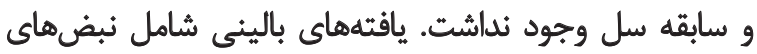

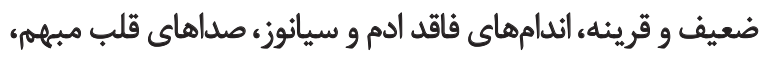

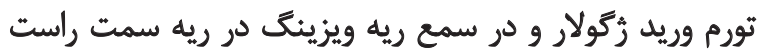

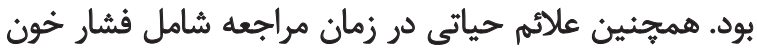

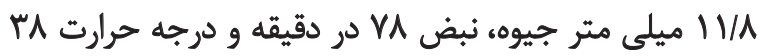

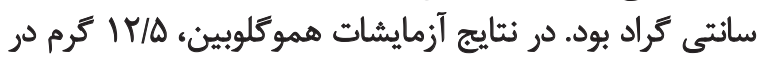

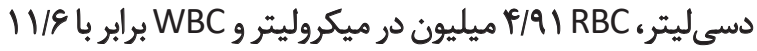

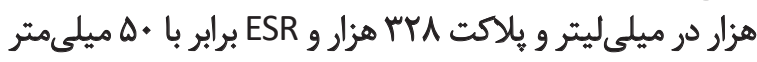

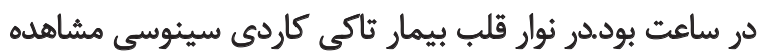

آر جه طى سال هاى اخير بيمارى سل كاهش هشمغيرى در

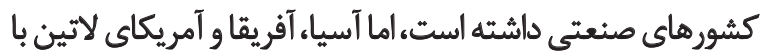

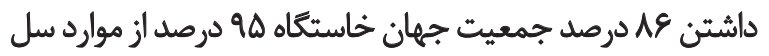

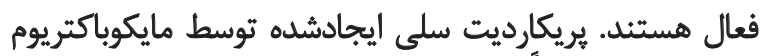

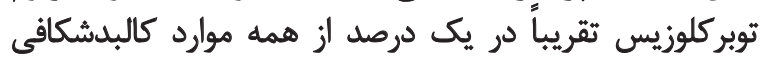

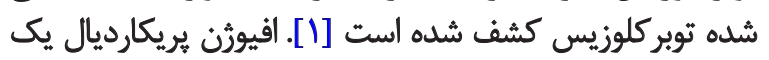

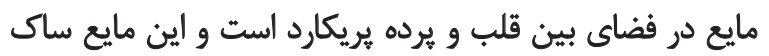

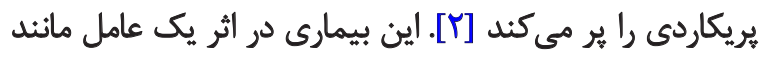

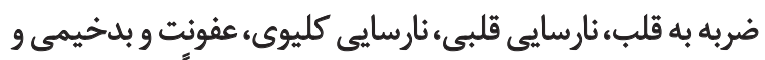

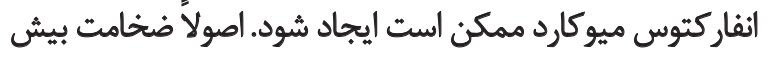

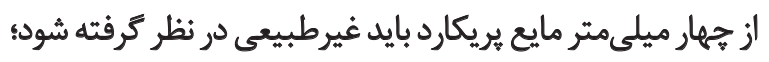

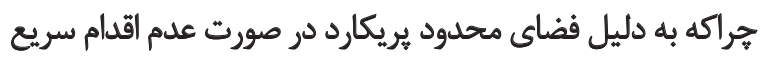

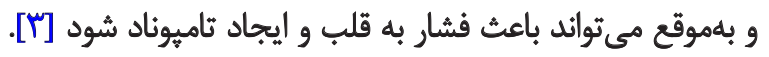

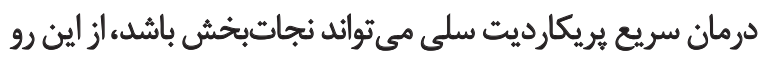

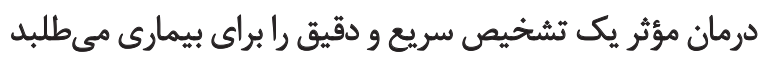

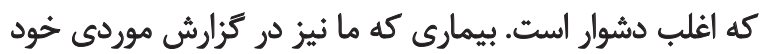




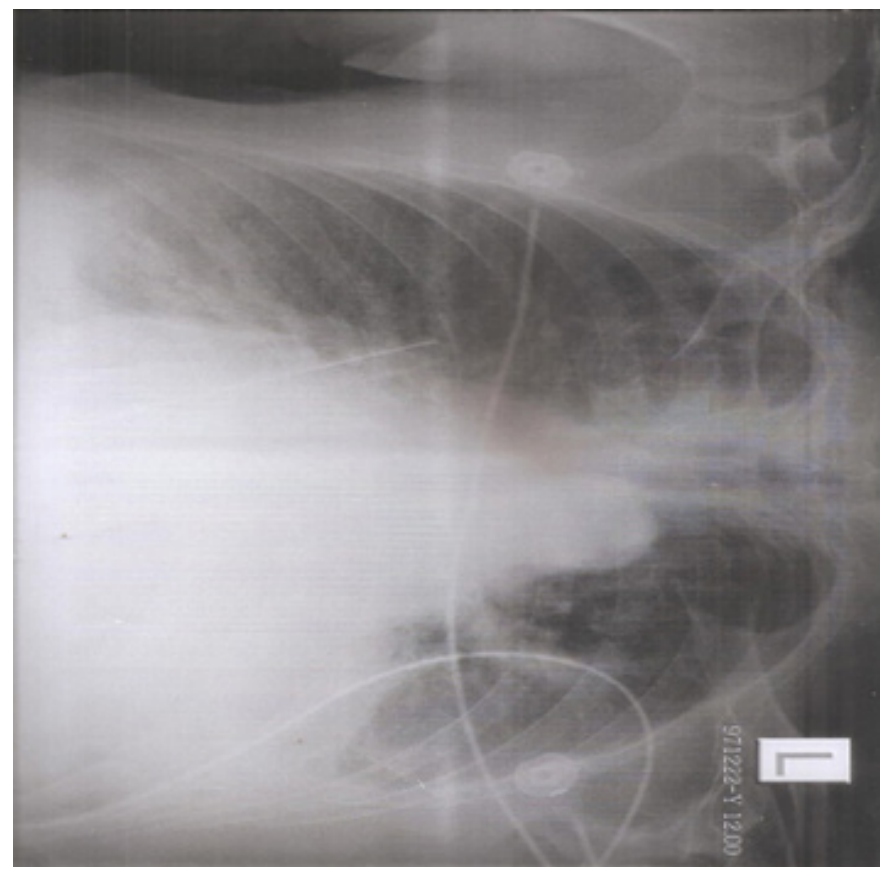

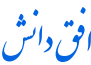

تصوير ا. كارديومنالى بيمار

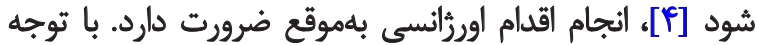

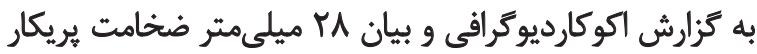

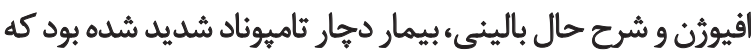

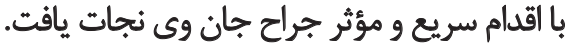

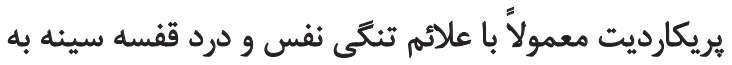

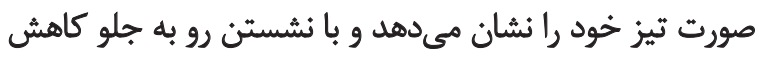

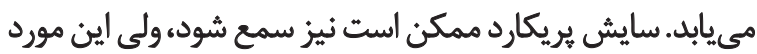

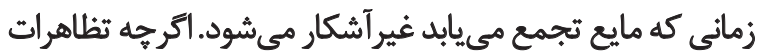

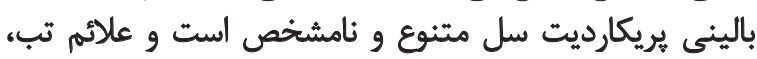

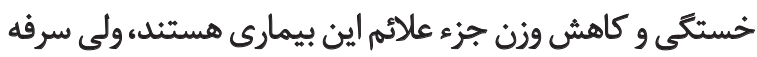

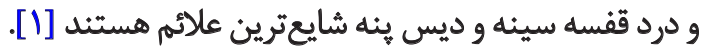

تاميوناد قلب نيز زمانى اتفاق مي افتئد كه مايع در فضاي

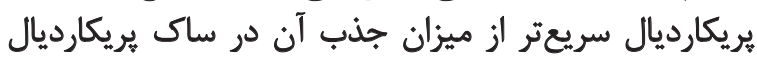

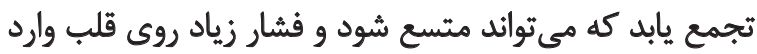

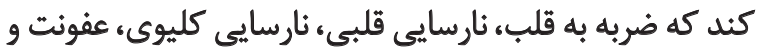

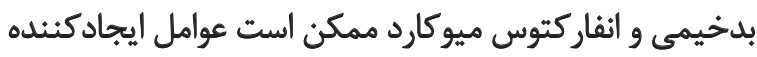

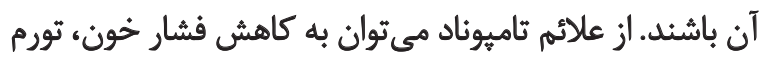

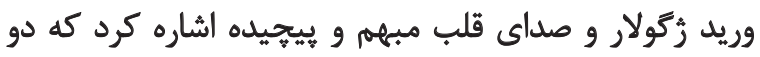

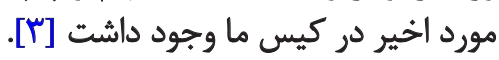

علاوه بر علائم بالينى بيمار، اكو و عكس قفسله سينها، براي

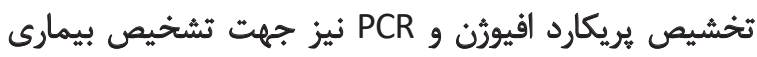

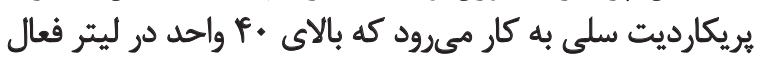

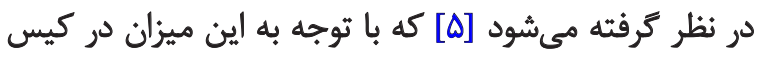

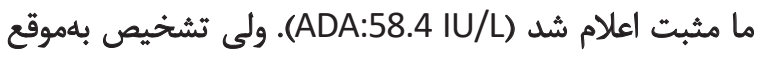

شد و در عكس قفسه سينه كارديومكالى مشاهده شد (تصوير

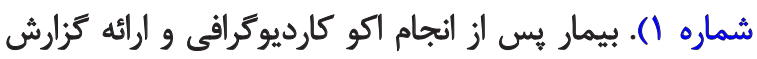

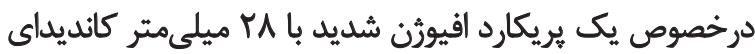

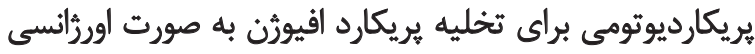

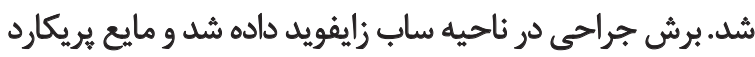

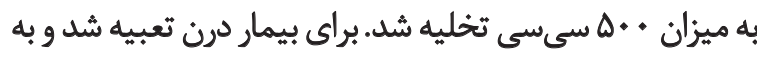

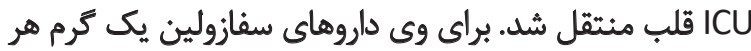

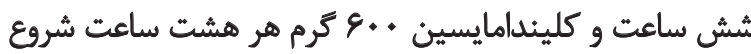

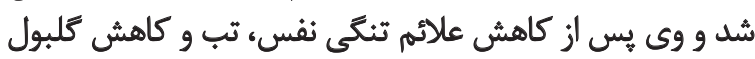

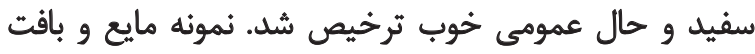

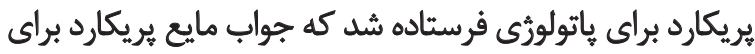

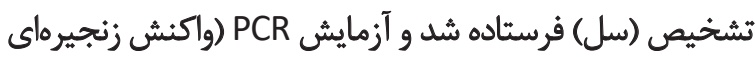

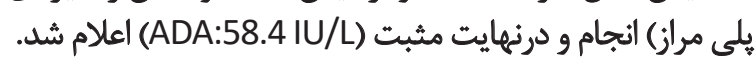

\section{بحث ونتيجهَيرى}

يريكارديت سلى رايجترين علت يريكارديت در آفريقا و ساير

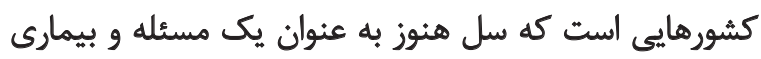

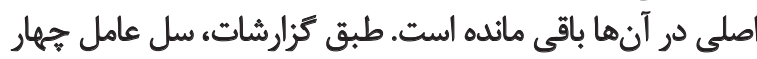

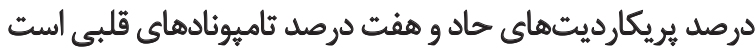

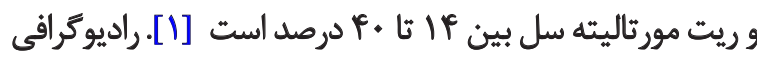

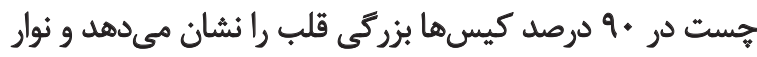

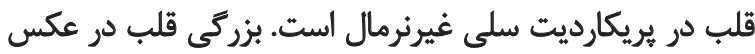

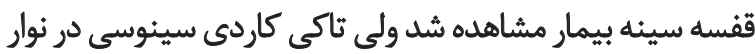

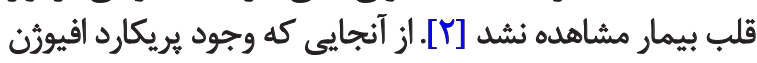

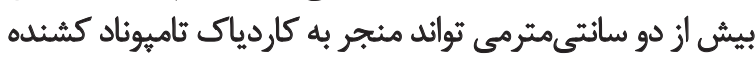


و صحيح اين بيمارى باعث كاهش علائم و بهببودى بيمار شد.

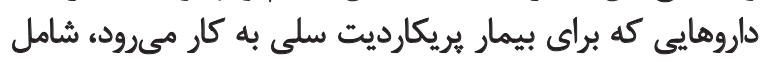

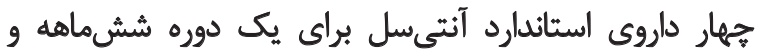

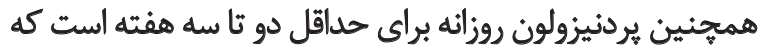
در كيس ما براي بيمار تجويز شد.

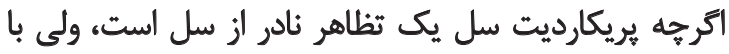

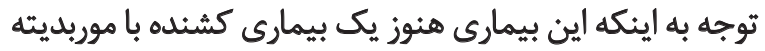

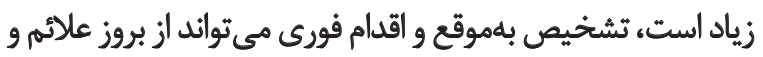

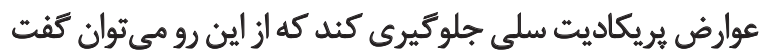

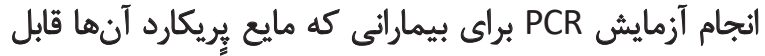

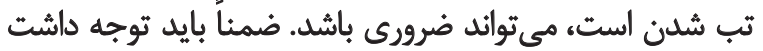

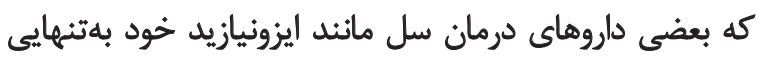

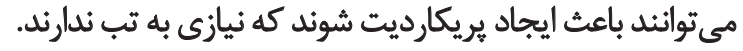

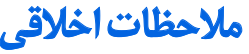

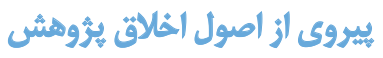
براى انجام ثرؤهش رضايتنامه كتبى از بيمار اخذ شد.

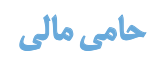

اين مقاله حامى مالى ندارد.

مشاركت نويسندكًان

تمام نويسندكان در طراحي، اجرا و نكارش همه بخشهاى ئروهش حاضر مشاركت داشتهاند.

تعارض مناقع

بنابر اظهار نويسندكان اين مقاله هيجّونه تعارض منافعى ندارد. 


\section{References}

[1] Wanjari K, Baradkar V, Mathur M, Kumar S. A case of tuberculous pericardial effusion. Indian Journal of Medical Microbiology. 2009; 27(1):75-7. http://www.ijmm.org/text.asp?2009/27/1/75/45179

[2] Montandon M, Wake R, Raimon S. Pericardial effusion complicated by tamponade: A case report. South Sudan Medical Journal. 2012; 5(4):89-91. https://www.ajol.info/index.php/ssmj/article/ view/132569

[3] Bogaert J, Francone M. Cardiovascular magnetic resonance in pericardial diseases. Journal of Cardiovascular Magnetic Resonance. 2009; 11:14. [DOI:10.1186/1532-429X-11-14] [PMID] [PMCID]

[4] Devaraj NK. Case report: A case of pericardial effusion presenting to primary care. The Medical Journal of Malaysia. 2017; 72(4):252-3. [PMID]

[5] Denk A, Kobat MA, Balin SO, Kara SS, Dogdu O. Tuberculous pericarditis: A case report. Le Infezioni in Medicina. 2016; 24(4):337-9. [PMID] 
This Page Intentionally Left Blank 